\title{
PENERAPAN ANALISIS VALUE ENGINEERING DENGAN TEORI TRIZ PADA SUBSTRUCTURE PROYEK X
}

\author{
Steven $^{1}$, Johny Johan ${ }^{2}$ \\ ${ }^{1}$ Mahasiswa Program Studi Magister Teknik Sipil, Universitas Tarumanagara \\ Email: stevenjc93@gmail.com \\ ${ }^{2}$ Dosen Program Studi Magister Teknik Sipil, Universitas Tarumanagara \\ Email: johnyjohan@gmail.com
}

Masuk: 26-12-2018, revisi: 18-08-2019, diterima untuk diterbitkan: 26-08-2019

\begin{abstract}
ABSTRAK
Kesuksesan suatu proyek merupakan hal yang ingin dicapai oleh seluruh pihak yang terlibat di dalamnya. Inefisiensi struktur yang terdapat dalam suatu proyek dapat menghalangi pencapaian kesuksesan yang diharapkan dalam suatu proyek. Oleh karena itu, diperlukan suatu teknik yang dapat menanggulangi permasalahan tersebut. Salah satu teknik yang dapat digunakan adalah value engineering. Dalam beberapa studi, telah dilakukan modifikasi pada analisis teknik value engineering. Salah satu modifikasi yang dimaksud adalah dengan menerapkan teknik TRIZ. Penerapan teknik TRIZ dalam analisis value engineering diyakini dapat memberikan kemudahan dalam menemukan solusi dalam permasalahan yang dihadapi. Struktur pondasi suatu proyek high rise building akan dijadikan objek studi. Studi ini bertujuan untuk menemukan sistem pondasi yang dapat diterapkan pada objek studi. Teknik TRIZ yang dilakukan dalam studi ini hanya diterapkan dalam fase kreatif yang terdapat di dalam analisis value engineering. Sistem awal pondasi yang diterapkan dalam objek studi adalah sistem bored pile foundation. Sistem bored pile foundation memiliki total biaya pelaksanaan sebesar Rp 18.719.136.609,24, penurunan rata-rata sebesar $48,24 \mathrm{~cm}$, waktu pelaksanaan selama 92 hari, dan skor penilaian sebesar 122,92. Penerapan teknik TRIZ dalam analisis value engineering memberikan dua buah alternatif, yaitu sistem raft foundation dan raft-pile foundation. Evaluasi yang dilakukan terhadap ketiga sistem yang dianalisis memberikan hasil bahwa sistem raft-pile foundation memberikan hasil yang paling baik dengan total biaya pelaksanaan sebesar Rp 15.910.991.105,30, penurunan ratarata sebesar $14,17 \mathrm{~cm}$, waktu pelaksanaan selama 87 hari, dan skor penilaian sebesar 144,58. Sistem raft-pile foundation memberikan penghematan biaya sebesar $15 \%$ terhadap sistem bored pile foundation.
\end{abstract}

Kata Kunci: bored pile foundation; matriks kontradiksi; raft-pile foundation; TRIZ; value engineering

\begin{abstract}
The success of a project is something that all parties involved in it want to achieve. The structure inefficiency found in a project can hinder the achievement of expected success in a project. Therefore, we need a technique that can overcome these problems. One technique that can be used is value engineering. In several studies, modifications have been made to the analysis of value engineering techniques. One modification is meant by applying the TRIZ technique. The application of TRIZ techniques in value engineering analysis is believed to provide convenience in finding solutions to the problems encountered. The foundation structure of a high rise building project will be the object of study. This study aims to find a foundation system that can be applied to the object of study. The TRIZ technique used in this study is only applied in the creative phase contained in the value engineering analysis. The initial foundation system applied in the object of study is the bored pile foundation system. The bored pile foundation system has a total implementation cost of Rp. 18,719,136,609.24, an average reduction of $48.24 \mathrm{~cm}$, an implementation time of 92 days, and an assessment score of 122.92. The application of the TRIZ technique in value engineering analysis provides two alternatives, namely the raft foundation system and the raft-pile foundation. Evaluations conducted on the three systems analyzed give the result that the raft-pile foundation system provides the best results with a total implementation cost of Rp. 15,910,991,105.30, an average decrease of $14.17 \mathrm{~cm}$, an implementation time of 87 days, and assessment score of 144.58. The raft-pile foundation system provides a cost savings of $15 \%$ over the bored pile foundation system.
\end{abstract}

Keywords: bored pile foundation; contradiction matri; raft-pile foundation; TRIZ; value engineering 


\section{PENDAHULUAN}

Kesuksesan suatu proyek merupakan hal yang ingin dicapai oleh seluruh pihak yang terlibat di dalamnya. Pada dasarnya, kesuksesan suatu proyek tidak dinilai hanya berdasarkan terselesaikannya proyek tersebut sesuai dengan batas waktu yang telah ditentukan, tetapi juga dari seberapa efisien struktur yang telah direncanakan untuk dilaksanakan. Untuk menanggulangi permasalahan tersebut, diperlukan teknik yang dapat diterapkan dalam proyek yang dimungkinkan bisa lebih efisien dalam segi biaya, waktu, dan mutu proyek tersebut. Salah satu teknik yang dapat diterapkan untuk menanggulangi masalah inefisiensi yang terjadi pada suatu proyek adalah value engineering (VE). Berawi et al. (2014) menyatakan VE merupakan suatu pendekatan multidisiplin untuk melakukan cara yang sistematis dalam menganalisis dan meningkatakan fungsi, biaya, dan nilai atas produk, desain, sistem atau jasa. Atabay dan Galipogullari (2013) mengingatkan bahwa VE tidak selalu memangkas biaya, tetapi dapat meningkatkan nilai barang maupun produk serta jasa. Dell'Isola (1997) menyatakan VE harus dilaksanakan sedini mungkin sebelum adanya komitmen dana, persetujuan sistem, layanan, atau desain untuk memaksimalkan hasil.

Analisis dengan metode VE dapat menghasilkan keuntungan besar apabila pelaksanaannya disertai dengan adanya ide-ide yang kreatif, mudah dan dapat dilaksanakan, serta menghasilkan resiko yang lebih sedikit. Dalam penelitian ini, bagian substructure suatu proyek high rise building akan dijadikan sebagai objek studi penelitian. Penerapan VE dalam perencanaan bagian bangunan tersebut dilakukan dalam beberapa tahapan. Salah satu tahapan yang dilakukan adalah tahapan kreatif. Tahapan ini pun dapat dimodifikasi dengan beberapa teknik, salah satunya adalah teknik TRIZ. Ilevbare et al. (2013) dan Mao et al. (2009) menyatakan TRIZ merupakan suatu akronim dalam Bahasa Rusia, yaitu teorija rezhenija izobretatelskih zadach atau dalam Bahasa Inggris adalah theory of inventive problem solving (teori penyelesaian masalah inventif) yang telah dikembangkan oleh Genrich Altshuller pada tahun 1946. Gadd dan Oxford Creativity (2011) menyatakan TRIZ merupakan suatu teknik unik, teliti, dan kuat yang dapat memandu insinyur dalam memahami dan menyelesaikan permasalahan yang mereka hadapi dengan mengakses harta yang besar pada pengetahuan sains dan teknik pada masa lampau. Domb dan Dettmer (1999) menyatakan bahwa penelitian TRIZ dimulai dengan hipotesis yang menyatakan bahwa terdapat asas-asas universal mengenai penemuan yang menjadi dasar dalam inovasi kreatif pada teknologi maju dan apabila asas-asas ini dapat diidentifikasikan, maka peneliti TRIZ dapat mengajarkan kepada orang-orang untuk membuat proses penemuan lebih mudah diprediksi. Penerapan atas modifikasi dan pengembangan teknik TRIZ dalam analisis VE dapat memberikan pola pemikiran tambahan dalam meningkatkan efisiensi dan efektivitas dalam menemukan ide-ide yang inovatif.

Dalam penelitian ini, terdapat masalah-masalah yang akan dibahas dan dianalisis, antara lain:

a. Teknik dan sistem substructure manakah yang dapat memberikan biaya, waktu, dan mutu yang lebih baik bila diterapkan pada objek studi?

b. Apakah dengan penerapan teknik TRIZ pada VE akan memberikan kemudahan dalam menganalisis objek studi dibandingkan dengan teknik konvensional VE?

Berdasarkan rumusan masalah di atas, maka tujuan dari penelitian ini adalah untuk:

a. Mencari teknik dan sistem substructure yang dapat diterapkan dalam objek studi untuk memperoleh biaya, waktu, dan mutu paling baik.

b. Mempelajari teknik TRIZ yang diterapkan pada teknik VE saat menganalisis objek studi yang diteliti serta kemudahan yang dihasilkan bila dibandingkan dengan teknik konvensional VE. 
Apabila penerapan teknik TRIZ dalam analisis VE yang dilaksanakan dalam penelitian ini dapat memberikan kemudahan dan hasil yang baik untuk bidang konstruksi, maka teknik ini dapat dikembangkan lebih lanjut untuk sektor konstruksi lainnya dan juga teknik TRIZ dapat diajukan kepada pakar maupun ahli dalam menganalisis VE. Hal ini memberikan manfaat dalam mengembangkan teknik analisis VE di masa mendatang.

\section{METODE PENELITIAN}

Data-data yang digunakan pada penelitian ini merupakan data sekunder, yaitu data yang diperoleh dari pihak kedua. Proyek yang dijadikan sebagai objek studi dalam penelitian ini berlokasi di Gading Serpong, Tangerang. Bangunan ini memiliki 1 (satu) main building yang direncanakan dengan 17 lapis lantai unit dan 3 (tiga) lapis basement. Fungsi bangunan ini adalah sebagai mixed used building yang direncanakan akan terdapat kantor, hotel, dan pusat perbelanjaan. Proyek ini memliki luas lahan sebesar $\pm 42.000 \mathrm{~m}^{2}$ dan luas bangunan sebesar \pm $33.693 \mathrm{~m}^{2}$. Penelitian ini dilakukan dengan beberapa tahapan yang dapat dilihat pada diagram alir pada Gambar 1 dari awal perencanaan sampai dengan kesimpulan yang dapat diambil dari hasil penelitian ini.

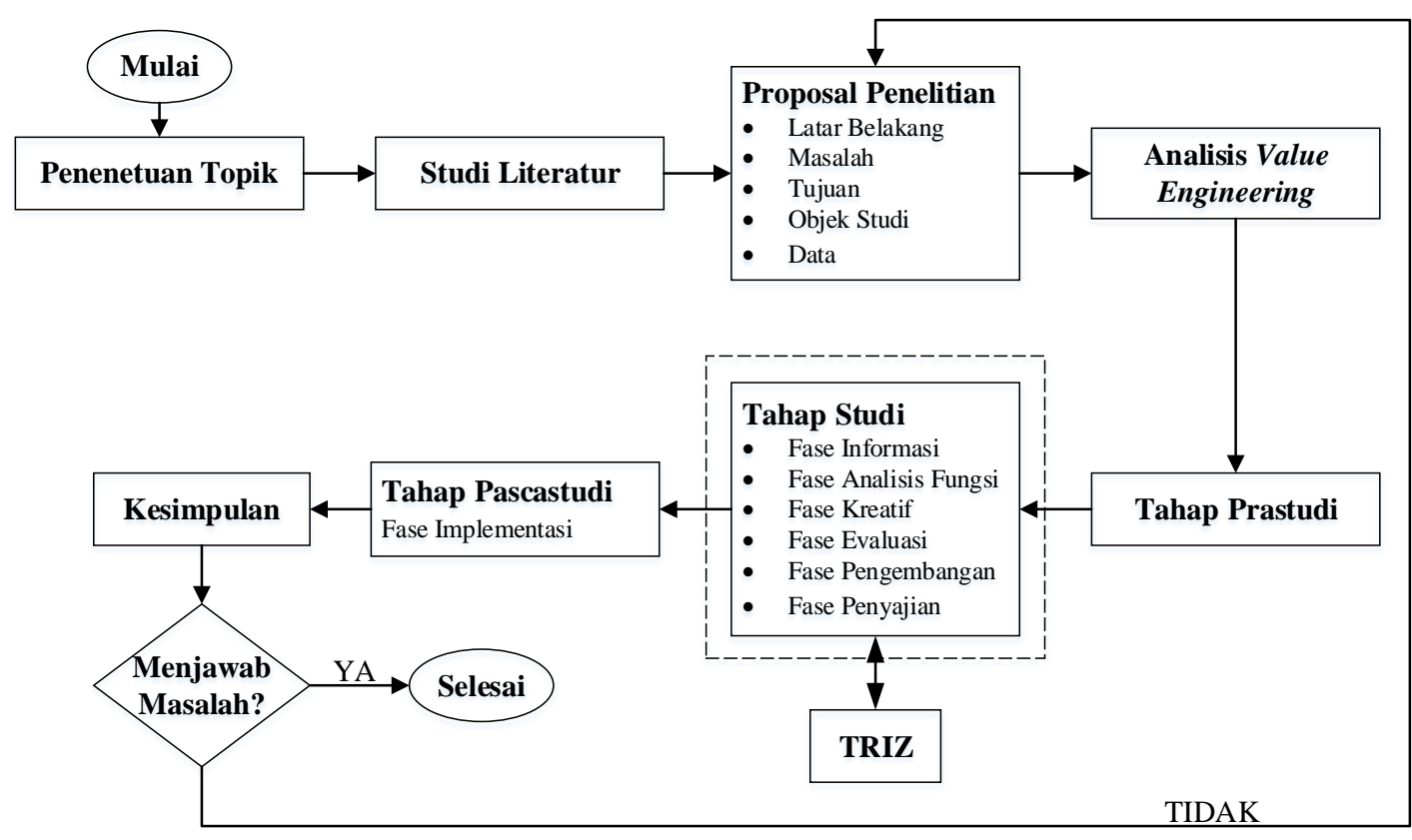

Gambar 1. Diagram Alir Penelitian

\section{HASIL DAN PEMBAHASAN}

Penelitian ini diawali dengan analisis dengan menggunakan teknik VE murni, kemudian dilanjutkan dengan analisis penerapan teknik TRIZ pada teknik VE sebagai teknik pembanding dengan objek penelitian adalah sistem pondasi suatu proyek. Analisis VE dalam penelitian ini terdiri atas tiga tahapan antara lain tahap prastudi, tahap studi, dan tahap pascastudi. Penerapan teknik TRIZ pada teknik VE dilakukan pada tahap studi, tepatnya dalam fase kreatif dan diilustrasikan dalam Gambar 2. 


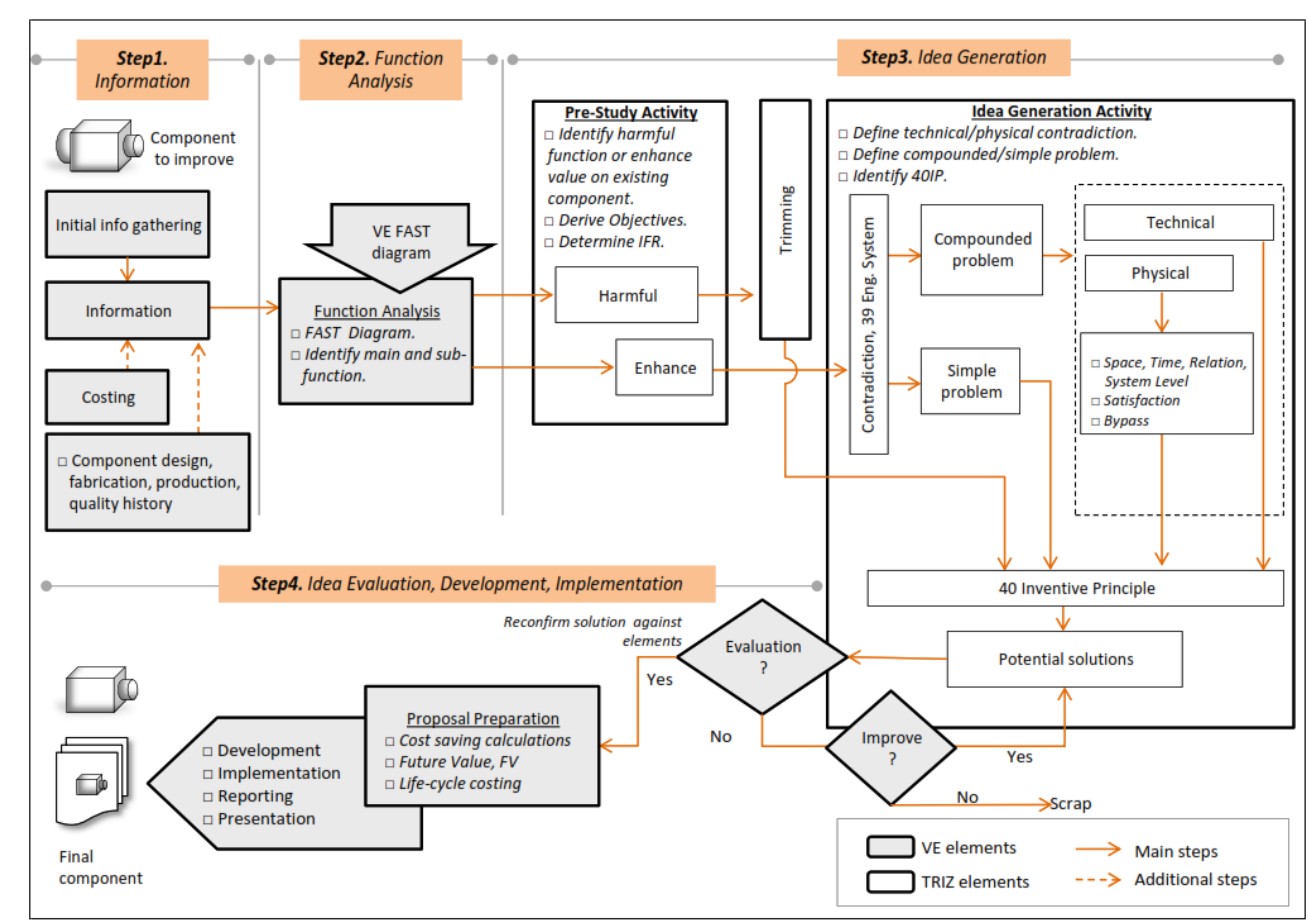

Gambar 2. Diagram Alir Tahap Studi Penerapan Teknik TRIZ pada Analisis Value Engineering (Sumber: Zamrah dan Sharif, 2015)

\section{Tahap prastudi}

Dalam penentuan proyek yang digunakan sebagai objek studi, penggunaan bangunan dengan jenis high rise building sebagai objek studi akan memberikan hasil yang cukup terlihat. Proyek high rise building yang digunakan berlokasi di Gading Serpong, Tangerang dengan jumlah lapisan lantai bangunan sebanyak 17 lapis lantai unit pada area tower dan 3 (tiga) lapis lantai pada area basement. Bangunan proyek ini akan difungsikan sebagai mixed use building yang dapat digunakan sebagai hunian, kantor, dan tempat perbelanjaan.

\section{Tahap studi - fase informasi}

Dalam laporan rekomendasi yang diberikan oleh tim konsultan geoteknik, dituliskan bahwa sistem pondasi yang dapat diterapkan pada objek studi adalah sistem bored pile. Sistem struktur pondasi yang direncanakan berdasarkan hasil yang terdapat dalam laporan soil investigation adalah dengan menggunakan bored pile yang berdiameter $60 \mathrm{~cm}$ dan $100 \mathrm{~cm}$, serta dengan kedalaman masing-masing bored pile adalah $18 \mathrm{~m}$ yang dihitung dari lapisan tanah asli. Permasalahan yang dihadapi dalam proyek ini antara lain sistem struktur pondasi yang tidak efektif dengan ditemukannya jarak antar tiang bor yang sangat dekat dan banyak elemen struktur yang memiliki dimensi yang cukup besar. Selain itu, pemilik proyek menganggap desain sistem bored pile foundation masih memiliki biaya yang cukup besar dan mengharapkan adanya pengurangan biaya struktur pondasi. Oleh sebab itu, dilaksanakan analisis VE untuk mendapatkan sistem pondasi yang sesuai dan tepat untuk diterapkan dalam proyek ini. Biaya total pekerjaan sistem bored pile foundation dengan total biaya pekerjaan sebesar Rp 18.719.136.609,24.

\section{Tahap studi - fase analisis fungsi}

Teknik VE dapat menganalisis fungsi pondasi bangunan proyek yang diulas sebagai permasalahan yang dihadapi dengan menggunakan teknik FAST diagram yang menggambarkan fungsi pondasi dalam objek studi. 


\section{Tahap studi - fase kreatif}

Untuk mempersingkat waktu, analisis VE murni tidak ditampilkan dalam penulisan ini. Analisis dalam fase ini dilakukan dengan menerapkan teknik TRIZ. Analisis ini diawali dengan mengidentifikasi terlebih dahulu permasalahan yang terdapat di dalam objek studi dengan menggunakan IFR (Ideal Final Result) yang terdapat pada teknik TRIZ. Kunci yang tedapat dalam IFR merupakan konsep dasar idealitas, yaitu meningkatkan benefit dan mengurangi biaya maupun kerugian yang dapat terjadi. IFR menyatakan perlunya dilaksanakan analisis untuk memperoleh suatu sistem pondasi yang dapat mengurangi dampak-dampak yang telah diulas sebelumnya. Dampak-dampak tersebut menghasilkan sebuah pertentangan secara teknis pada sistem pondasi yang menjadi objek studi. Hal ini mungkin dapat dilakukan dengan mengurangi elemen struktur yang sudah ada dalam sistem bored pile foundation atau dengan menggunakan jenis pondasi lain dengan pertimbangan-pertimbangan maupun persyaratan yang ada dalam peraturan.

Berdasarkan permasalahan yang terdapat dalam sistem pondasi awal, perlu dianalisis sistem pondasi yang dapat bekerja lebih baik dan tepat diterapkan dalam proyek yang dijadikan bahan studi. Perlu diuraikan terlebih dahulu kebutuhan pemilik proyek dan tindakan apa yang dapat dilakukan untuk memenuhi kebutuhan pemilik proyek. Sebagai hasil analisis yang dilakukan dengan teknik diskusi bersama dalam kelompok, Tabel 1 akan mengulas seluruh kebutuhan pemilik proyek terhadap struktur pondasi beserta kebutuhan teknis yang perlu dilakukan dan akan menjadi bagian analisis dengan menggunakan teknik-teknik yang disediakan dalam TRIZ.

Tabel 1. Parameter-Parameter Altshuller Terhadap Kebutuhan Teknis dan Kebutuhan Owner

\begin{tabular}{|c|c|c|c|c|}
\hline \multirow{2}{*}{ No. } & \multirow[t]{2}{*}{ Kebutuhan Owner } & \multirow{2}{*}{ Kebutuhan Teknis } & \multicolumn{2}{|c|}{ Parameter Altshuller } \\
\hline & & & Improving & Worsening \\
\hline 1. & $\begin{array}{l}\text { Pondasi kuat terhadap } \\
\text { beban yang bekerja. }\end{array}$ & $\begin{array}{l}\text { Elemen struktur pondasi } \\
\text { didesain kokoh dan } \\
\text { sesuai peraturan yang } \\
\text { berlaku. }\end{array}$ & Strength (14) & Shape (12) \\
\hline \multirow[t]{2}{*}{2.} & \multirow{2}{*}{$\begin{array}{l}\text { Pekerjaan struktur } \\
\text { pondasi tidak memakan } \\
\text { banyak waktu. }\end{array}$} & \multirow{2}{*}{$\begin{array}{l}\text { Desain pondasi harus } \\
\text { mudah dilaksanakan di } \\
\text { lapangan. }\end{array}$} & $\begin{array}{c}\text { Weight of Stationary } \\
\text { Object }(2)\end{array}$ & Strength (14) \\
\hline & & & Shape (12) & Ease of Operation (33) \\
\hline \multirow[t]{2}{*}{3.} & \multirow{2}{*}{$\begin{array}{l}\text { Biaya pembuatan } \\
\text { pondasi yang tidak } \\
\text { besar. }\end{array}$} & \multirow{2}{*}{$\begin{array}{l}\text { Elemen struktur pondasi } \\
\text { didesain dengan ukuran } \\
\text { yang tepat dan tidak } \\
\text { begitu besar. }\end{array}$} & $\begin{array}{c}\text { Ease of Operation } \\
\text { (33) }\end{array}$ & $\begin{array}{c}\text { Object Generated } \\
\text { Harmful (31) }\end{array}$ \\
\hline & & & $\begin{array}{c}\text { Ease of Operation } \\
\text { (33) }\end{array}$ & $\begin{array}{c}\text { Weight of Stationary } \\
\text { Object (2) }\end{array}$ \\
\hline
\end{tabular}

Teknik TRIZ yang digunakan dalam analisis ini adalah dengan menggunakan Teknik 40 Asas Inventif. Hal pertama yang perlu dilakukan sebelum melakukan analisis ini, yaitu mengidentifikasi parameter-parameter teknis yang dialami sebagai bagian permasalahan yang dihadapi berdasarkan kebutuhan-kebutuhan teknis. Seluruh parameter teknis pada masingmasing kebutuhan teknis yang terdapat dalam Tabel 1 memiliki hubungan dan akan disusun menjadi suatu matriks yang dinamakan matriks kontradiksi yang merupakan salah satu teknik yang disediakan TRIZ untuk menanggulangi kontradiksi teknis yang dialami. Hubungan masingmasing parameter yang terdapat dalam matriks kontradiksi menghasilkan asas-asas inventif yang dapat memberikan solusi terhadap masalah yang disajikan oleh pengguna metode ini. Hasil analisis dan penyusunan matriks kontradiksi yang telah dibuat berdasarkan parameter-parameter teknis yang terdapat dalam Tabel 1 dapat dilihat dalam Gambar 4 berikut ini. 


\begin{tabular}{|c|c|c|c|c|c|c|}
\hline \multirow{2}{*}{\multicolumn{2}{|c|}{$\begin{array}{l}\text { Worsening } \\
\text { Feature } \\
\text { Improving } \\
\text { Feature }\end{array}$}} & 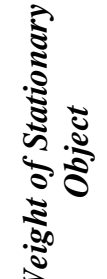 & $\frac{\Xi}{5}$ & 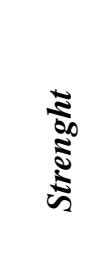 & 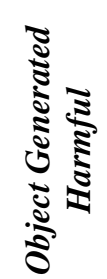 & 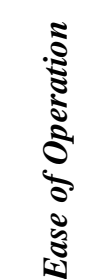 \\
\hline & & 2 & 12 & 14 & 31 & 33 \\
\hline 2 & $\begin{array}{c}\text { Weight of } \\
\text { Stationary Object }\end{array}$ & + & $\begin{array}{l}10,13, \\
14,29 \\
\end{array}$ & $\begin{array}{l}2,10, \\
27,28 \\
\end{array}$ & $\begin{array}{r}1,22 \\
35,39 \\
\end{array}$ & $\begin{array}{c}1,6, \\
13,32\end{array}$ \\
\hline 12 & Shape & $\begin{array}{l}3,10, \\
15,26\end{array}$ & + & $\begin{array}{l}10,14, \\
30,40\end{array}$ & 1,35 & $\begin{array}{c}15, \\
26,32\end{array}$ \\
\hline 14 & Strenght & $\begin{array}{l}1,26, \\
27,40\end{array}$ & $\begin{array}{l}10,30, \\
35,40\end{array}$ & + & $\begin{array}{l}2,15, \\
22,35\end{array}$ & $\begin{array}{l}2,25, \\
32,40\end{array}$ \\
\hline 33 & $\begin{array}{c}\text { Ease of } \\
\text { Operation }\end{array}$ & $\begin{array}{c}1,6, \\
13,25\end{array}$ & $\begin{array}{l}15,28, \\
29,34\end{array}$ & $\begin{array}{l}3,28, \\
32,40\end{array}$ & + & + \\
\hline
\end{tabular}

Gambar 4. Matriks Kontradiksi dan Asas-Asas Inventif yang dapat Diterapkan Dalam Objek Studi

Dalam matriks kontradiksi yang terdapat pada Gambar 4, analisis berikutnya dilakukan dengan memilih asas-asas inventif yang ditentukan dengan munculnya nomor asas inventif sebanyak minimal dua kali dalam matriks kontradiksi. Hasil pemilihan asas-asas inventif ini dapat dilihat dalam Tabel 2 berikut ini.

Tabel 2. Asas-Asas Inventif yang Dipilih

\begin{tabular}{clcl}
\hline $\begin{array}{c}\text { No. } \\
\text { Asas }\end{array}$ & \multicolumn{1}{c}{ Asa Inventif } & $\begin{array}{c}\text { No. } \\
\text { Asas }\end{array}$ & \multicolumn{1}{c}{ Asa Inventif } \\
\hline 1 & Segmentation & 25 & Self-Service \\
2 & Taking Out & 26 & Copying \\
3 & Local Quality & 27 & Cheap Shoty-Living Objects \\
6 & Universality & 28 & Replace Mechanical System \\
10 & Preliminary Action & 29 & Pneumatics and Hydraulics \\
13 & The Other Way Round & 30 & Flexible Shells \& Thin Films \\
14 & Spheroidality Curvature & 32 & Color Changes \\
15 & Dynamics & 35 & Parameter Changes \\
22 & Convert Harm Into Benefit & 40 & Composite Materials \\
\hline
\end{tabular}

Selanjutnya perlu dipelajari mengenai solusi umum yang diberikan masing-masing asas inventif yang terdapat dalam Tabel 2 untuk menentukan asas-asas inventif yang sesuai untuk menyelesaikan masalah yang ada dalam analisis ini. Adapun Tabel 3 menunjukkan hasil analisis dan pertimbangan-pertimbangan terhadap asas-asas inventif yang akan digunakan untuk menyelesaikan masalah yang sedang dihadapi akibat adanya kontradiksi teknis. 
Tabel 3. Analisis Asas-Asas Inventif yang Dipilih pada Matriks Kontradiksi dan Solusi yang Dihasilkan

\begin{tabular}{|c|c|c|}
\hline $\begin{array}{l}\text { Asas-Asas } \\
\text { Inventif }\end{array}$ & Solusi Umum yang Diberikan TRIZ & Solusi yang Diperoleh \\
\hline 6. Universality & $\begin{array}{l}\text { Mengaplikasikan objek yang dapat } \\
\text { melakukan banyak fungsi yang } \\
\text { berbeda, sehingga dapat } \\
\text { mengurangi kebutuhan dari objek- } \\
\text { objek lainnya. }\end{array}$ & $\begin{array}{l}\text { Sistem pondasi menggunakan sistem raft } \\
\text { foundation yang dapat mengurangi } \\
\text { penggunaan tie beam dan pile cap. }\end{array}$ \\
\hline 3. Local Quality & $\begin{array}{l}\text { Transisi dari struktur homogem } \\
\text { objek atau di luar lingkungan } \\
\text { menjadi struktur heterogen. }\end{array}$ & $\begin{array}{l}\text { Gunakan gabungan pondasi yang dapat } \\
\text { memaksimalkan fungsi pondasi, yaitu } \\
\text { dengan menggabungkan seluruh elemen tie } \\
\text { beam, pelat lantai, dan pile cap menjadi } \\
\text { satu, sehingga bertindak sebagai raft yang } \\
\text { bekerja sama dengan bored pile. Sistem ini } \\
\text { merupakan sistem raft-pile foundation. }\end{array}$ \\
\hline 10. Prior Action & $\begin{array}{l}\text { Lakukan sebagian atau seluruh } \\
\text { tindakan yang diperlukan terlebih } \\
\text { dahulu. } \\
\text { - Menyusun objek-objek sehingga tidak } \\
\text { perlu menunggu waktu yang lama } \\
\text { untuk melakukan tindakan. }\end{array}$ & $\begin{array}{l}\text { Melakukan pekerjaan perkuatan tanah } \\
\text { terlebih dahulu yang dapat meningkatkan } \\
\text { daya dukung dengan menggunakan secant } \\
\text { pile atau pengangkuran, sehingga } \\
\text { penggunaan struktur pondasi dapat efektif. }\end{array}$ \\
\hline
\end{tabular}

Berdasarkan analisis dengan matriks kontradiksi, diperoleh tiga buah alternatif yang dapat dilaksanakan. Ketiga alternatif tersebut antara lain:
a. Penggunaan raft foundation.
b. Penggunaan raft-pile foundation.
c. Melaksanakan perbaikan tanah bila diperlukan.

Hasil yang diberikan sebagai hasil analisis dengan teknik VE murni dan penerapan teknik TRIZ ke dalam analisis kreatif VE memberikan hasil yang serupa. Hasil yang diberikan adalah dengan menerapkan dua buah alternatif sistem pondasi, yaitu sistem raft foundation dan raft-pile foundation.

\section{Tahap studi - fase evaluasi}

Analisis yang dilakukan dalam fase ini dilakukan berdasarkan segi waktu, biaya, mutu, dan analisis yang disediakan dalam teknik VE. Secara ringkas, hasil analisis yang dilihat dari segi waktu, biaya, dan mutu dapat dilihat dalam Tabel 4 berikut ini.

Tabel 4. Ringkasan Hasil Evaluasi Waktu, Biaya, dan Mutu Seluruh Sistem Pondasi

\begin{tabular}{lccc}
\hline Sistem Pondasi & Waktu (hari) & Biaya (Rp) & Mutu, Settlement (cm) \\
\hline Bored Pile & 92 & $18.719 .136 .609,24$ & 48,24 \\
Raft & 73 & $16.605 .298 .512,90$ & 16,59 \\
Raft-Pile & 87 & $15.910 .991 .105,30$ & 14,17 \\
\hline
\end{tabular}


Selain melihat pada unsur biaya, waktu, dan mutu, perlu dilaksanakan analisis evaluasi sistem berdasarkan teknik-teknik yang disediakan dalam teknik VE. Analisis yang dilaksanakan pada fase evaluasi VE diawali dengan menentukan kriteria-kriteria yang dijadikan acuan dalam menilai ketiga sistem pondasi yang akan dievaluasi. Kriteria-kriteria yang telah ditentukan ini kemudian diberikan bobot nilai pada masing-masing kriteria dan kemudian hasilnya disusun dengan menggunakan Simple T-Chart yang ditunjukkan pada Tabel 5 berikut ini.

Tabel 5. Simple T-Chart

\begin{tabular}{clc}
\hline No. & Kriteria & Bobot Nilai \\
\hline 1. & Resiko & 1 \\
2. & Biaya & 3 \\
3. & Mutu & 2 \\
4. & Waktu Pelaksanaan & 2 \\
5. & Kemudahan Pelaksanaan & 2 \\
\hline
\end{tabular}

Selanjutnya, kriteria-kriteria dalam Tabel 5 akan dikelola kembali dengan perbandingan masingmasing kriteria dengan pemberian nilai antara 0 hingga 10 . Hasil pengelolaan nilai masingmasing kriteria ini dapat dilihat dalam Tabel 6 berikut ini.

Tabel 6. Bobot Penilaian Masing-Masing Kriteria

\begin{tabular}{cccccccccccccc}
\hline No. & Kriteria & \multicolumn{8}{c}{ Relative Weight for Decisions Options } & $\begin{array}{c}\text { Total Relative } \\
\text { Weight }\end{array}$ & $\begin{array}{c}\text { Assignment } \\
\text { Weight }\end{array}$ \\
\cline { 3 - 11 } & & $\mathbf{1}$ & $\mathbf{2}$ & $\mathbf{3}$ & $\mathbf{4}$ & $\mathbf{5}$ & $\mathbf{6}$ & $\mathbf{7}$ & $\mathbf{8}$ & $\mathbf{9}$ & $\mathbf{1 0}$ & & \\
\hline 1. & Resiko & 4 & 3 & 5 & 6 & & & & & & & 18 & 7,5 \\
2. & Biaya & 6 & & & & 6 & 6 & 6 & & & & 24 & 10 \\
3. & Mutu & & 7 & & & 4 & & & 5 & 7 & & 23 & 9,58 \\
4. & Waktu Pelaksanaan & & & 5 & & & 4 & & 5 & & 5 & 19 & 7,92 \\
5. & Kemudahan Pelaksanaan & & & & 4 & & & 4 & & 3 & 5 & 16 & 6,67 \\
\hline
\end{tabular}

Analisis selanjutnya yang dapat diterapkan dalam mengevaluasi sistem-sistem alternatif ini adalah dengan menggunakan teknik scoring, yaitu dengan memberikan nilai pada masingmasing sistem pondasi yang dianalisis. Adapun Tabel 7 berikut ini menunjukkan teknik scoring sebagai lanjutan evaluasi setelah mendapatkan nilai acuan (assignment weight) masing-masing kriteria yang telah ditentukan dalam Tabel 6.

Tabel 7. Teknik Evaluasi dengan Scoring

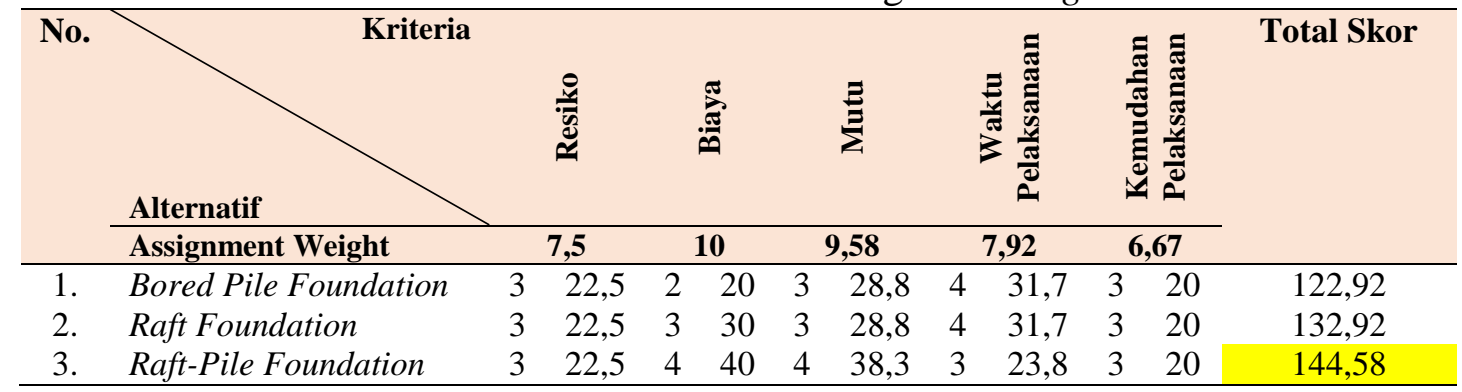

Berdasarkan hasil evaluasi yang telah dilaksanakan, maka diperoleh bahwa sistem raft-pile foundation memberikan hasil yang paling baik dibandingkan dengan kedua sistem pondasi lainnya. 


\section{Tahap studi - fase pengembangan}

Sistem pondasi yang dipilih setelah dievaluasi adalah sistem raft-pile foundation. Pada fase ini, sistem pondasi yang telah dipilih akan dirangkum dan dilihat perubahan yang terjadi bila dibandingkan dengan sistem pondasi awal. Perbandingan antara sistem bored pile foundation terhadap sistem raft-pile foundation memberikan penghematan sebesar $15 \%$ atau sebesar Rp 2.808.145.503,94.

\section{Tahap pascastudi - fase implementasi}

Berdasarkan hasil analisis yang telah dilakukan, raft-pile foundation ditetapkan sebagai sistem pondasi yang paling cocok diimplementasikan untuk dilaksanakan dalam proyek tersebut. Sistem ini memberikan biaya yang lebih kecil dan penurunan pondasi yang lebih minim dari sistemsistem alternatif lainnya.

\section{KESIMPULAN DAN SARAN}

\section{Kesimpulan}

Hasil yang diperoleh dapat disimpulkan sebagai berikut.

a. Sistem pondasi paling sesuai untuk diterapkan dalam objek studi adalah sistem raft-pile foundation.

b. Sistem raft-pile foundation memberikan hasil yang baik dari segi biaya, mutu, waktu, dan penilaian yang terdapat dalam teknik VE dibandingkan dengan sistem bored pile foundation dengan hasil sebagai berikut.

- Settlement rata-rata sistem raft-pile foundation sebesar $14,17 \mathrm{~cm}$ lebih kecil daripada settlement rata-rata sistem bored pile foundation sebesar 48,24 cm.

- Biaya pelaksanaan sistem raft-pile foundation sebesar Rp 15.910.991.105,30 lebih kecil dibandingkan biaya pelaksanaan sistem bored pile foundation sebesar $\mathrm{Rp}$ 18.719.136.609,24. Hal ini menyebabkan sistem raft-pile foundation memberikan penghematan biaya sebesar $15 \%$.

- Waktu pelaksanaan sistem raft-pile foundation 5 hari lebih cepat daripada waktu pelaksanaan sistem bored pile foundation ( 87 hari $<92$ hari) tanpa memperhitungkan adanya kendala yang terjadi di proyek.

- Total skor penilaian sistem raft-pile foundation adalah paling besar dibandingkan sistem bored pile foundation dan sistem raft foundation.

Selain hasil analisis sistem pondasi yang disimpulkan, penerapan teknik TRIZ ke dalam teknik VE memberikan sumbangan yang baik dalam mengolah permasalahan yang dihadapi. Hal ini dapat dilihat dalam konsep berpikir TRIZ yang bertujuan sama dengan konsep berpikir VE. VE bertujuan untuk memperoleh suatu nilai yang baik terhadap barang maupun jasa, sedangkan TRIZ bertujuan untuk memperoleh suatu idealitas terhadap barang maupun jasa. Pandangan VE menitik beratkan pada fungsi dan kualitas barang maupun jasa terhadap biayanya, sedangkan pandangan TRIZ menitik beratkan pada benefit yang diterima terhadap biaya yang telah dikeluarkan dan dapat merugikan barang maupun jasa.

TRIZ juga memberikan hasil yang baik dalam menemukan solusi terhadap permasalahan yang dihadapi. Kontradiksi teknis yang muncul pada kebutuhan teknis juga dapat dieliminasi dengan bantuan asas-asas inventif yang terdapat dalam matriks kontradiksi. Analisis dengan matriks kontradiksi juga tidak lepas dengan adanya diskusi bersama dengan beberapa orang sehingga hasilnya lebih baik dan objektif. 


\section{Saran}

Penelitian lebih lanjut mengenai penerapan teknik TRIZ dalam analisis VE perlu dikembangkan dengan melakukan beberapa hal berikut.

1. Penerapan teknik-teknik kreatif yang disediakan TRIZ selain dengan menggunakan matriks kontradiksi dalam menghasilkan ide-ide yang dapat meningkatkan benefit dan mengeliminasi kerugian-kerugian yang dihasilkan dalam objek studi.

2. Analisis lebih lanjut perlu dilakukan pada sistem struktur selain pada sistem pondasi yang dianalisis dalam penelitian ini.

Selain itu, sama halnya dengan analisis yang menggunakan teknik VE, analisis dengan teknik TRIZ juga harus dilaksanakan bersama beberapa orang sebagai tim. Hal ini dilakukan supaya dengan berdiskusi dan mempelajari bersama-sama teknik-teknik yang disediakan pada teknik TRIZ akan diperoleh hasil yang lebih baik dan bersifat objektif.

\section{REFERENSI}

Atabay, S. dan Galipogullari, N. (2013). Application of Value Engineering in Construction Projects. J. of Traffic and Transportation Eng., 1(1), 39-48.

Berawi, M. A., Susantono, B., Miraj, P., Berawi, A. R. B., Rahman, H. Z., dan Husin, A. (2014). Enhancing Value for Money of Mega Infrastructure Projects Development Using Value Engineering Method. Elsevier Procedia Technology, 16, 1037-1046.

Dell'Isola, A. (1997). Value Engineering: Practical Application. United States of America: RS Means Company Inc.

Domb, E. dan Dettmer, H. W. (1999). Breaktrhrough Innovation in Conflict Resolution: Marrying TRIZ and the Thinking Process. USA: A Goal System International.

Gadd, K., dan Oxford Creativity. (2011). TRIZ for Engineers: Enabling Inventive Problem Solving. United Kingdom: John Wiley \& Sons, Ltd.

Ilevbare, I. M., Probert, D., Phaal, R. (2013). A Review of TRIZ, and Its Benefits and Challenges

Mao, X., Zhang, X., AbouRizk, S. M. (2009). Enhancing Value Engineering Process by Incorporating Inventive Problem-Solving Techniques. J. Const. Eng. Manage., 135(5), 416-424.

Zamrah, Z. S. dan Sharif, S. (2015). Integration of Value Engineering and TRIZ-Theory of Inventive Problem Solving: A Theoretical Framework in Malaysian Automotive Industry. Technology J., 77:33, 171-176. 